Araştırma Makalesi - Research Article

\title{
Varyans Analizi (ANOVA) ve Kovaryans Analizi (ANCOVA) İle Deney Tasarımı: Bir Gıda İşletmesinin Tedarik Süresine Etki Eden Faktörlerin Belirlenmesi
}

\begin{abstract}
Beyzanur Çayır Ervural ${ }^{1 *}$
Geliş / Received: 13/04/2020

Revize / Revised: 09/07/2020

Kabul / Accepted: 10/07/2020

\section{öZ}

Küreselleşme ile rekabet koşullarının giderek ağırlaştığı günümüz şartlarında işletmelerin varlıklarına devam edebilmesi etkin tedarik zinciri faaliyetleri ile mümkündür. İyi yönetilen bir ağ mekanizmasında, sipariş edilen ürünün doğru yer ve doğru zamanda teslim edilmesinin yanı sıra kaliteli, sürdürülebilir ve paydaşlarla doğrudan iliş̧ili etkin bir tedarik zincir ağına ihtiyaç vardır. Bu çalışmada bir gıda işletmesinin tedarik zinciri a ğ yönetiminde tedarik süresine etki eden faktörler belirlenerek, etkin faktörlerin tedarik süresi ile ilişkisi araştırılmıştır. Buna göre varyans analizi (ANOVA) ve kovaryans analizi (ANCOVA) ile entegre bir deney tasarımı gerçekleştirilmiş ve elde edilen sonuçlar karşılaştııılmıştır. Etkin faktör seviyeleri arasında farklılıkları görmek için Duncan ve Tukey testleri uygulanmıştır. Elde edilen sonuçlara göre işletmenin tedarik zinciri performansı iyileştirilerek taktiksel ve stratejik seviyede kararlar alınmasına yardımcı olunması amaçlanmıştır.
\end{abstract}

Anahtar Kelimeler- Tedarik Süresi, Deney Tasarımı, ANOVA, ANCOVA

\footnotetext{
1*Sorumlu yazar iletişim: beyzanur.ervural@gidatarim.edu.tr (https://orcid.org/0000-0002-0861-052X)

Endüstri Mühendisliği, Mühendislik ve Mimarlık Fakültesi, Konya Gıda ve Tarım Üniversitesi, 42080 Konya, Türkiye
} 


\title{
Design of Experiment with Variance Analysis (ANOVA) and Covariance Analysis (ANCOVA): Determination of Effective Factors Affecting the Lead Time in a Food Company
}

\begin{abstract}
In today's market environments, where globalization and competition conditions are getting harder, it is possible for companies to continue their existence with effective supply chain activities. In addition to delivering the ordered product at the right place and at the right time, a supply chain network that is directly related to stakeholders should be designed through a quality, sustainable and well-managed network mechanism. In supply chain network management, chain activities should be maintained by taking advantage and adapting to current, dynamic, and existing developments. In this study, the factors affecting lead time in a food company's supply chain network management were determined, and the relationship between effective factors and the lead time was investigated. Accordingly, an integrated design of experiment was conducted with analysis of variance (ANOVA) and analysis of covariance (ANCOVA), and the obtained results were compared to each other. Duncan and Tukey tests were used to see differences between levels of effective factors. According to the obtained results, it was aimed to improve the supply chain performance and aid the company in order to make decisions at the tactical and strategic levels.
\end{abstract}

Keywords- Lead time, Design of experiment, ANOVA, ANCOVA 


\section{GİRIS}

Tedarik zinciri yönetimi, hammaddenin elde edilmesinden ürünün nihai müşteriye teslim edilmesine kadarki süreçte sistemde yer alan tedarikçi, üretici, perakendeci ve müşteriler arasındaki ürün, para, bilginin en iyi biçimde kontrol edilmesine dayanan bir yönetim bilimidir. Müşterinin istediği anda malzeme veya ürüne ulaşabilmesi ancak hammadde, yarı mamul veya ara malzemenin zamanında temin edilmesi ile mümkündür. $\mathrm{Bu}$ açıdan değerlendirildiğinde tedarik süresinin tedarik zinciri yönetiminde kritik öneme sahip olduğu görülmektedir. Tedarik zinciri hammaddenin nihai ürüne dönüşüne kadarki safhalarında yer alan müşteri, tedarikçi ve fabrika gibi zincir elemanlarıyla doğrudan ilişkilidir. Zincirdeki elemanların birinde meydana gelecek değişiklik/aksaklık tüm sistemi etkilemektedir. Bu sebeple sürecin en iyi şekilde düzenlenerek organize edilmesine, sistemin ve var olan kaynakların optimize edilmesine ihtiyaç vardır.

Tedarik zinciri yönetiminde en temel unsur müşteri memnuniyetinin karlılık ve kalite entegrasyonuyla birlikte sağlanmasıdır. Buradan yalnızca kaliteli ürün üretmenin yeterli olmadığı anlaşılmakta ve müşteriye ürünün ne zaman, nereye, nasıl, ve ne miktarda ulaştırılacağının koşulları etkin biçimde incelenmelidir. $\mathrm{Bu}$ aşamada tedarik zinciri yönetiminin geniş perspektiften değerlendirilmesi gerekmektedir. Çünkü işletmelere girdi sağlayarak son müşteriye ulaşan ve satış sonrası hizmetler sunan şirketlerin de tedarik zinciri ağında yer aldığı bilinen bir gerçektir. Tedarik zincirindeki her halkanın doğru biçimde koordine edilmesi sürecin bütününün kusursuz işlemesine yardımcı olmaktadır. Global Tedarik Zinciri Forumu'nda, tedarik zinciri yönetiminin aşamalarını şu şekilde kabul edilmiştir: 1) Müssteri İlişkileri Yönetimi (Customer Relationship Management) 2) Müşteri Hizmet Yönetimi (Customer Service Management) 3) Talep Yönetimi (Demand Management) 4) Sipariş İşleme (Order Fulfillment) 5) İmalat Akış Yönetimi (Manufacturing Flow Management) 6) Satın alma (Procurement) 7) Ürün Geliştirme ve Ticarileştirme (Product Development and Commercialization) 8) İadeler (Returns). Tedarik zincirini doğru biçimde yönetmenin firmalara sağlayacağı pek çok yarardan söz edilebilir. Bu yararlar Tedarik Zinciri Konseyi (Supply Chain Council) tarafindan şu şekilde özetlenebilir: Tedarik ağı boyunca verimliliğin artması, maliyetin azalması, çevrim sürelerinin kısalması, stok miktarı ve maliyetinin düşmesi, teslim politikalarında iyileşme, doğru tahmin kabiliyeti ve verimlilik/kapasite artı̧ıının sağlanmasıdır.

Etkin yürütülen tedarik zinciri politikası ile zincirdeki paydaşlar arasındaki koordinasyon sayesinde ortaya çıkabilecek belirsizlikler önlenecek ve bu sayede fazla stok ortaya çıktığında oluşacak maliyetlerin önüne geçilecektir. Ayrıca zincirdeki güçlü işbirliği ve doğru iletişim sayesinde karşlıklı güven oluşacak dolayısıyla ortaya çıkabilecek riskler paylaşılarak yeni başarılı işler ortaya konacaktır. Yeni ürün tasarımı, yeni ürünün piyasaya hızlı girişinin sağlanması gibi bir takım yenilikler firmalara avantaj sağlayacaktır. Bu sayede müşteri memnuniyeti sağlanarak firmalar için kazanç artışı, gereksiz stok yatırımının önlenmesi, yeni ürün geliştirme faaliyetlerinin artışı ve müşteriye hızlı yanıt verme süresi ile büyük kazanımlar elde edilecektir. Görüldüğ̈̈ gibi rekabetin yalnızca rakip firmalar arasında olmadığı, tedarik sürecine katılan tüm paydaşlar arasında tedarik zincirindeki uyumluluğun ve tutarlılığın sağlanması, akışın bozulmaması açısından söz konusu olmaktadır [1]. Aksi takdirde tedarik ağ süreci sıkıntıya gireceği için müssteri ve prestij kayıpları söz konusu olacağından rakip firmalar avantaj sağlayacaktır. Bunun önüne geçilmesi için zincirde yer alan tüm unsurların uyumluluk içinde faaliyet göstermesi her an değişikliklere yanıt verebilecek güç ve altyapıda olması gerekmektedir.

Bu çalışmada bir gıda şirketinin tedarik zinciri faaliyetleri kapsamında tedarik süresine etki eden faktörler belirlenerek teslim süresinin en aza indirilmesi amaçlanmaktadır. İşletmeler için teslim süresi hayati önem taşımaktadır. Müşteriye hızlı yanıt verebilme müşteri memnuniyetinin yansıra özellikle raf ömrü kısa, hızlı bozulabilen gıda ürünlerinde zaman yönetimi açısından önemlidir. Aksi durumda hem müşteri kaybı hem de ürün kaybı söz konusu olacaktır. Çalışmada ANOVA ve ANCOVA yöntemlerinin deney tasarımı ile entegre edilerek tedarik süresinin belirlenmesinde iki aşamalı istatistiksel metot kullanılması hem uygulama alanı hem de yöntemsel olarak literatüre katkı sağlamaktadır. Çalışmada, tedarik süresine etki eden faktörler belirlenerek işletmenin taktiksel ve stratejik seviyede karar almasına yardımcı olunmaktır. Bu sayede şirketin uzun vadede ayakta kalması desteklenmekte ve rakiplerine karşı izleyeceği politikaların şekillenmesine katkı sağlanmaktadır.

Çalışmanın izleyen bölümünde tedarik zinciri yönetimi ile ilgili literatür araştırması sunulmuş ardından üçüncü kısımda tedarik zinciri yönetiminin gelişimi anlatılmıştır. Dördüncü bölümde, çalışmada kullanılan deney tasarımı, varyans analizi ve kovaryans analizi yöntemleri açıklanmıştır. Beşinci kısımda, bir gıda işletmesi 
için tedarik süresi varyans analizi ve kovaryans analizi yöntemleri ile değerlendirilmiştir. Altıncı bölümde yapılan analizler ve elde edilen sonuçlar sunulmuştur. Son olarak yedinci bölümde, sonuçlar ve gelecek araştırmalar için öneriler paylaşılmıştır

\section{LITERATÜR ARAŞTIRMASI}

Tedarik zinciri yönetimiyle ilgili literatürde yapılan çalışmalar şu şekilde sunulabilir: Perçin [2] çalışmasında bilgi teknolojileri ile tedarik zincirinin zamana dayanan performansını değerlendirmiş ve buna göre Türk otomotiv yan sanayisinin performansını ölçmek için bir model geliştirmiştir. Elde edilen model sonucuna göre firmaların bilgi teknolojileri ve süreç geliştirme yöntemlerinin tedarik zinciri zamana dayalı performans ölçütü üzerinde olumlu etkisi olduğu görülmüştür. Yayla ve Hartomacıoğlu [3] seramik sektöründe faaliyet gösteren tedarikçileri değerlendirmek için eş zamanlı mühendislik metodunun kullanım etkinliğine göre faktör analizi yardımıyla yapay sinir ağları ile süreci analiz etmişlerdir. Yangınlar [4] turizm sektöründe tedarikçi seçim kriterlerini belirleyerek işletmeler arasında istatistiksel açıdan bir farklılık olup olmadığını tespit etmiştir. Aytekin ve Özcan [5] nitelikli elektronik sertifika tedarik başvuru çevrim süreleri açısından ANOVA ile performansları değerlendirilmiştir. Yang ve diğ. [6] çevrimiçi doğrudan kanaldaki çift kanallı bir tedarik zincirindeki teslim süresini analiz etmişlerdir. Yazarlar stok dışı kalma durumunda değişen müşteri davranışının teslim süresinin genişlemesinde Newsvendor modelini kullanmışlardır. Fu ve Yeh [7] bütünleşik üretici-satın alıcı tedarik zinciri teslim maliyeti ve taşıma süresinin etkisini değerlendirmiştir.

Schniederjans ve diğ. [8] çalışmalarında, bilgi yönetiminden yararlanarak gelecekteki tedarik zinciri araştırmasını geliş̧irmiştir. Böylece tedarik zinciri dijital performansını optimize etmek amacıyla hem literatür araştırması hem de endüstri ve saha uygulamaları üzerindeki tahminler ve metin araştırmalarını incelenmiştir. Munir ve diğ. [9], risk yönetiminin bilgi işleme ile birleşiminde operasyonel performansı iyileştirmek için tedarik zinciri entegrasyonu ve tedarik zinciri risk yönetimi arasındaki ilişkiyi araştırmaktadır. Böylece tedarik zinciri risk yönetimi tarafından yönetilen aracı rolü kovaryans tabanlı yapısal eşitlik modellemesi kullanarak işletmenin operasyonel performansı ve tedarik zinciri entegrasyonu ile araştırılmıştır. Chen ve diğ. [10], son kullanıcıları mutlu etmek ve satışları teşvik etmek için hizmet seviyesine bağlı tedarikçi ve perakendeciden oluşan bir tedarik zinciri ağını ele almaktadır. Yüksek talep oynaklığından kaynaklanan kayıpları azaltmak için, perakendeci alımları tedarikçiden ilk siparişini ayarlama seçenekleri koymaktadır. Çalı̧̧mada tedarik zinciri modelleri hem satış sözleşmesi hem de hizmet seviyesi kısııını kapsayacak şekilde genişletilmiş ve uygun üretim politikalarının yanı sıra en uygun sipariş politikası değerlendirilmiştir. Hizmet seviyesi kısııı altında en uygun sipariş ve üretim politikaları üretilmiştir. Helo ve Shamsuzzoha [11] çok şirketli proje ortamlarında tedarik zinciri yönetimi için ihtiyaçları ve gereklilikleri izleme teknolojileri ile değerlendirmiştir. Bu çalışma ayrıca lojistik ve tedarik zincirinin gerçek zamanlı izlenmesi için bulut tabanlı bir portalın pilot sistemini önermektedir. $\mathrm{Bu}$ portal, RFID, IoT ve blockchain teknolojisinin entegre bir gerçek zamanlı görünüme birleștirilmesiyle oluşturulmuştur. RFID (Radyo Frekansı Tanımlama) ve IoT (Nesnelerin İnterneti) gerçek zamanlı bilgi veya veri sağlarken, blok zincir teknolojisi değişmez işlemler zinciri sağlamak için kullanılmıştır. Roy ve diğ. [12] gelişmekte olan bir ekonomide faaliyet gösteren giyim üreticilerinin sürdürülebilir öğrenme çabalarını araştırmaktadır. Hazır giyim üreticisi tarafindan benimsenen farklı sürdürülebilir tedarik zinciri yönetim politikalarının çağdaş giyim tedarik zincirinin çevresel ve operasyonel performanslarına nasıl katkıda bulunduğunu açıklanmaktadır. Noori-Daryan ve diğ. [13], çalışmalarında fiyat ve teslim süresinin müşteriler için önemli öncelikler arasında yer aldığını belirtmiş ve özellikle eczane endüstrisindeki pazar talebinin satış fiyatına ve teslim süresine duyarlı olduğunu bildirmiştir. Bu açıdan çalışmada farmakolojik zincir üyeleri olarak çok uluslu, kapasite kısıtlı üreticiler dikkate alınmış ve tedarikçinin belirsizlik altında talepleri değerlendirilerek incelenmiştir.

Öztürk [14] tedarik zinciri yönetime etki eden faktörleri değerlendirmiştir. Bandaly ve diğ.[15] teslim süresi değişikliğinin tedarik zinciri risk yönetimindeki performansına olan etkisini araştırmıştır. Stokastik teslim zamanlı model önceki deterministik modelin genişletilmiş halidir. Operasyonel metotlar ve finansal araçlar kullanılarak risk yönetim yaklaşımını entegre eden fiyat riskini ve talep belirsizliğini baz almaktadır. Elde edilen bulgulara göre teslim zamanı değişikliğinin tedarik zinciri performansına her zaman zarar vermediği ortaya çıkmıştır. Yalnızca yüksek seviyeli teslim zamanı değişikliğinde koordineli tedarik zincirine ihtiyaç olmuştur. 
Literatür incelendiğinde tedarik zinciri çalışmalarının farklı kapsamlarda değerlendirildiği çoğunlukla da tedarikçi tercihlerine odaklanıldığ 1 gözlenmektedir. Bu çalışma, literatürden faklı olarak tedarik süresine etki eden parametreleri ayrıntılı biçimde değerlendirmekte buna göre varyans analizi (ANOVA) ve kovaryans analizi (ANCOVA) yapılarak bir deney tasarımı planlanmaktadır. Etkin faktörlerin seviyeleri arasında farklılıkları görmek için Duncan ve Tukey çoklu aralık testleri uygulanmıştır.

\section{TEDARIK ZINCIRI YÖNETIMININ GELIŞSIMI}

Tedarik zinciri yönetimindeki gelişmeler takip edildiğinde öncelikle taktiksel ve operasyonel seviyede gelişmeler söz konusu iken değişen pazar koşulları gereği stratejik yaklaşımlar geliştirilerek tedarik zinciri stratejilerine geçilmiştir. Tedarik zinciri yönetimi ile ilgili çalışmalar incelendiğinde 1960'lı yıllarda sürecin başladığı gözlenmiştir. Tedarik zinciri yönetiminin ilk aşaması olarak kabul edilen fiziksel dağıtım aşaması Bowersox tarafından kanal-içi bütünleşik yaklaşımın firmalara rekabet üstünlüğü sağlayacağını ifade etmiştir [16].

1970’lerde Malzeme İhtiyaç Planlaması sisteminin ortaya çıkmasıyla maliyet, kalite yeni ürün geliştirme ve dağıtım faaliyetlerinde tedarik sürelerinin önemi dikkat çekmiştir. Pazarlama, üretim ve finans kısmıyla ilgili süreç içi faaliyetlerin yürütülmesinde sistematik lojistik yönetimi ile idare edilmesi gerektiği anlaşılmıştır. Buna göre bütüncül bir yaklaşımla depolama, taşıma ve müşteri hizmetleri birleştirilerek tedarik zinciri yönetimin fiziksel dağıtım yönetimi aşamasına geçilmiştir [17].

1980’lerden itibaren müşteri odaklılık ve pazara yönelik faaliyetler önem kazanmış, tedarik zinciri yönetiminin ikinci aşaması olarak ifade edilen lojistiğin sistemle bütünleştirilmesi aşamasına geçilmiştir [17]. 1990'larda rekabet koşullarının zorlaşmasıyla sadece müşteri beklentilerini karşılamanın yeterli olmadığı, ürünlerin müşteriye tam zamanında, doğru miktarda ve düşük maliyetle ulaştırmanın gerekliliği anlaşılmıştır. Ürünü temin eden aracı tedarikçilerden başlayıp ürünü nihai müşteriye teslim eden işletmelere kadarki tüm süreçte tedarik ağı bütünün birlikte yönetilmesi gerektiği anlaşılmıştır. Böylece tedarik zinciri yönetim aşaması oluşmuştur [18]. Lojistik faaliyetlerinin de aktif biçimde zincir faaliyetlerine dahil edilmesiyle günümüz tedarik zinciri yönetimi oluşmuştur.

Bilgi teknolojilerinin ve internetin hızlı gelişimiyle tedarik zinciri yönetimine internet tabanlı e-ticaret ve e-tedarik gibi gerçek zamanlı talep kontrolü, sipariş verme, müşteri hizmetleri ve stok yönetimi gibi uygulamalar eklenmiş böylece E-Tedarik Zinciri Yönetim aşaması oluşmuştur [19].

\section{YÖNTEM}

Bu kısımda çalışmada kullanılan Deney Tasarımı, ANOVA ve ANCOVA yöntemleri açıklanarak yöntemlerin uygulama aşamaları gösterilmiştir.

\section{A. Deney Tasarımı}

Deney tasarımı, bir sürecin performansına etki eden parametrelerin sistematik bir yaklaşımla değerlendirilerek çıktının iyileşmesine yardımcı olan istatistiksel bir yaklaşımdır [20]. Deney tasarımında, problemde yer alan faktörler, faktör seviyeleri, problemin çıktı değişkeni ve hazırlanan deneysel çalışmanın uygun bir analiz metoduyla belirlenmesi gerekmektedir. Deney tasarımı bir sürecin optimizasyonunda, süreçte yer alan değişkenliğin azaltılmasının tespit edilmesinde önemlidir.

Deney tasarımı, özellikle bir sistem sürecinin iyileştirilmesi, kalite kontrolünün sağlanması ve sistem performansının arttırılmasında etkili rol oynamaktadır. Şekil 1'de bir sistem süreci genel biçimiyle sunulmuştur. Burada girdi ve çıktı değişkenlerin yanı sıra sistemde kontrol edilebilen ve kontrol edilemeyen faktörler yer almaktadır. Buna göre sistemde kontrol edilemeyen değişken etkisi en aza indirgenerek süreç performansı iyileştirilmeye çalışılmaktadır.

İstatistiksel deney tasarım yöntemleri tam faktöriyel tasarım, kesirli faktöriyel tasarımı ve taguchi metodu gibi farklı yöntemlerden oluşmaktadır. Bu çalışmada tam faktöriyel tasarım yöntemi kullanılmıştır. Birden fazla faktör olduğunda faktöriyel tasarım kullanılmaktadır. Tam faktöriyel deney tasarımında en az iki 
veya daha fazla faktör ve faktör seviyesinin yer aldığı deneylerde tüm faktör ve seviyeleri çarpılarak kombinasyonlar denenerek en uygun parametre seti araştırılır, böylece hangi faktörün hangi seviyede olması gerektiği belirlenerek süreçteki optimum koşullar sağlanmaktadır. Tam faktöriyel deney tasarımı Varyans analizi ve regresyon analizleriyle birleştirilerek değerlendirilmektedir. Böylece hangi faktörün ilgili süreçte etkili olduğu araştırılarak faktörün deney üzerindeki etkisi hesaplanabilmektedir [21].

Doğru planlanmış bir deney tasarımı ile zaman, kaynak ve bütçe tasarrufu yapılarak etkin sonuçlar elde edilebilmektedir. Deney tasarımı yapılırken üç temel varsayımın sağlanması gerekmektedir bunlar rassallık, tekrarlama ve bloklama özelikleridir. Rassallık yapılacak deneylerin rasgele bir biçimde birbirinden bağımsız biçimde olmasıdır. Böylece hata oranı azaltılmaya çalışılır. Tekrarlama bir deneyin birden fazla sayıda yaparak doğru sonuç elde edilmesi sağlanmakta, deneysel hata oranı engellenmektedir. Bloklamada her blokta yer alan deneyler kendi içinde değerlendirilerek süreçte etkili başka faktörler varsa etkisinin azaltılması amaçlanmakta sadece ilgilenilen faktörün etkisi tespit edilmektedir. Tam faktöriyel deney tasarımında tam bloklama kullanılır, böylece bilinmeyen veya kontrol edilemeyen hataların deneyi etkilemesi önlenir. Bu temel varsayımlar altında hazırlanan deney tasarımı homojen, doğru ve tutarlı biçimde oluşturulmaktadır.

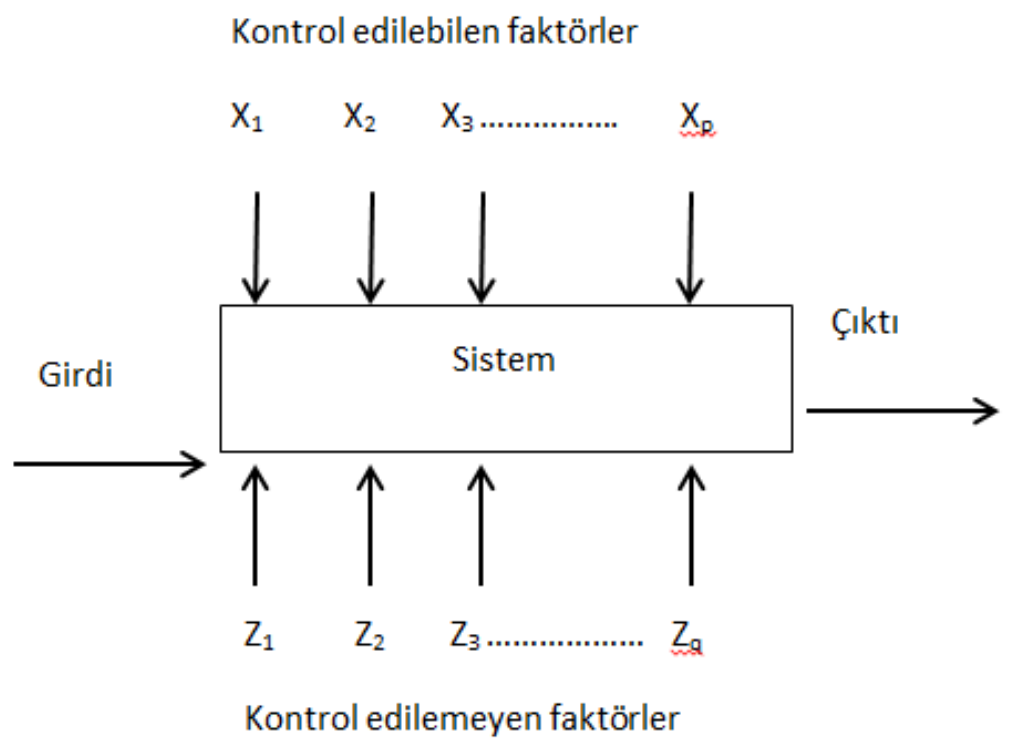

Şekil 1. Bir sistemin genel süreç yapısı [20]

\section{B. Varyas Analizi (ANOVA)}

Varyans analizi, iki farklı grup ortalamaları arasında fark olup olmadığını varyans kullanarak araştıran istatistiksel bir yaklaşımdır. İki grubun karşılaştııılmasında kullanılan farklı yöntemler olsa da ( $Z$ veya $T$ testi) en yaygın olanı $F$ testi yani Varyans Analizi (ANOVA, Analysis of Variance) dir. İkiden fazla grubun önem seviyesi değerlendirilmek istediğinde aralarındaki farklılık sadece Varyans Analizi ile yapılabilmektedir.

Analizde yalnız ölçülebilen değişken etkileri araştırılıyorsa çoklu regresyon analizi, hem ölçülebilen hem de ölçülemeyen bağımsız değişkenlerin etkileri araştırılırsa kovaryans analizi yapılmaktadır. Ayrıca çoklu regresyon analizi ile de ölçülebilen ve ölçülemeyen değişkenlerin bağımlı değişken üzerindeki etkisi, ölçülmeyen değişkenin "dummy" değişken olarak tanıtılmasıyla analize dahil edilir [22], [23]. Tek faktörlü varyans analizinde bir bağımsız değişken ve bir bağımlı değişken vardır. İki faktörlü varyans analizinde ise iki bağımsız değişken ve bir bağımlı değişken yer almaktadır. Burada temel amaç, bağımsız değişkenlerin bağımlı değişkenler üzerindeki ortak etkisinin araştırılmasıdır. Ayrıca, bağımsız her bir değişkenle ilgili grubun bağımlı 
değiş̧ene göre ortalamaları karşılaştırılarak ortalamalar arasındaki farkın anlam düzeylerine göre önemli olup olmadığı araştırılır.

Varyans analizinin uygulanabilmesi için örneklem ana kütlesinin sahip olması gereken bazı özellikler bulunmaktadır. Her bir grubun normal dağılım sergilemesi, örneklerin bağımsız ve varyanslarının eşit olması istenmektedir. ANOVA analizinde kullanılan $F$ testi hipotezi şöyle oluşturulur:

$H_{o}: \mu_{1}=\mu_{2}=\mu_{3}=\cdots=\mu_{N}$ Ortalamalar arasında fark yoktur.
$H_{1}$ : Ortalamalar arasında en az iki arasında anlamlı bir fark vardır.

\section{Test İstatistiği}

Varyans analizinde temel amaç, ikiden fazla örnek için örnek ortalamalarının genel ortalamadan sapmalarının kareler toplamını, sapmaya yol açan etkileri ayırmak ve analiz etmektir. İki faktörlü varyans analizi modeli şu şekilde gösterilmektedir:

$$
X_{i j k}=\mu+\alpha_{i}+\beta_{j}+\alpha \beta_{i j}+e_{i j k}
$$

burada $\mu$, genel ortalamayı; $\alpha_{i}$ ilk faktör etkisini; $\beta_{j}$ ikinci faktörün etkisini ve $\alpha \beta_{i j}$ ortak etkiyi ifade ederken, $e_{i j k}$ hata terimini açıklamaktadır [24]. İki faktörlü varyans analizinde üç ayrı test işlemi yapılmaktadır.

1)Öncelikle, iki faktör bütün olarak anlamlı bir etkiye sahip mi bu durum incelenir. Burada açıklanabilen kareler toplamı dikkate alınarak $F$ test değeri şu formülle hesaplanır:

$$
F=\frac{\left(S S_{x}+S S_{y}+S S_{x y}\right) / d f_{x, y, x y}}{S S_{\text {error }} / d f_{\text {error }}}=\frac{M S_{x, y, x y}}{M S_{\text {error }}}
$$

burada, $S S_{x, y, x y} \mathrm{x}$, y ve ikili etkileşimini gösteren kareler toplamını (sum of squares), $M S_{x, y, x y}$ terimi, $x, y$ ve ikili etkileşimini gösteren kareler ortalamasını (mean of squares), $d f$ (degrre of freedom) serbestlik derecesini gösterir. Formülde yer alan $S S_{\text {error, }} M S_{\text {error }}$ ve $d f_{\text {error }}$ hatalar için kareler toplamı, kareler ortalaması ve serbestlik derecesini ifade etmektedir.

$$
\begin{aligned}
& d f_{X, Y, X Y}=\left(N_{X}-1\right)+\left(N_{Y}-1\right)+\left(N_{X}-1\right)\left(N_{Y}-1\right)=N_{X} N_{Y}-1 \\
& d f_{\text {error }}=k-N_{X} N_{Y}
\end{aligned}
$$

burada, $k$ örneklem sayısını ve $N$ ilgili faktörün(değişkenin) düzeyini göstermektedir. $F$ testine göre, anlamlı etkiye sahip olduğu sonucu çıkarsa $x, y, x y^{\prime}$ nin toplam etkisinin bağımlı değişken üzerinde bazı etkilerinden söz edilebilir.

2) Ardından ortak etkinin (interaction effect) anlamlılığ değerini vermektedir. Ortak etki anlamlı ise faktörlerin birbirleri üzerinde anlamlı bir etkiye sahip olduğu söylenebilir.

3) Daha sonra her bir değişken ana etkisi (main effects) araştırılır. Sabit etkiler modeline göre $F$ değerleri şöyle hesaplanır:

$$
F_{X}=M S_{x} / M S_{\text {error } \text { ve }} F_{Y}=M S_{y} / M S_{\text {error }}
$$

Görüldüğü gibi iki faktörlü varyans analizi, bağımsız değişkenlerin her birinin ana etkisi ve ortak etkilerinin anlamlılığı test edilerek araştırmacılara büyük kolaylık sağlamakta ve istatiksel olarak geniş açıdan yorumlama kabiliyeti sunmaktadır. 
ANOVA ve ANCOVA analizleri birbirleriyle yakından ilişkili konular olduğu için öncelikle ANOVA anlatılmış ardından ANCOVA yöntemi açıklanmıştır.

\section{Kovaryans Analizi (ANCOVA)}

Kovaryans analizi (ANCOVA- Analysis of Covariance), bağımsız değişkenlerin bağımlı değişken üzerindeki etkisini araştıran, ayrıca bağımlı değişken ile ilişkisi bulunan ortak değişkenlerin (covariate) analiz edilmesinde kullanılan varyans analizi ile regresyon analizini birlikte değerlendiren istatistiksel bir yöntemdir. Kovaryans analizinde ortak değişkenden kaynaklanan etki çıkartılarak, bağımlı değişkendeki değişimin bağımsız değişkenle ilişkisi araştırılmaktadır [25]. ANCOVA gerekli koşullar sağlandığında varyans analizinin düşünüldüğü her yerde kullanılabilen güçlü bir istatistiksel metot olarak tanımlanmaktadır [26]. Kovaryans analizi ile varyans analizi arasındaki temel fark, bağımlı değişken ile ilişkili olan ve ANOVA'da belirlenen bağımsız değişkenlerden farklı olarak bir yada daha fazla değişkenin kovaryant değişken olarak analize katılmasidır [27].

Kovaryans analizinde, öncelikle regresyon analizi uygulanır ardından varyans analizi gerçekleştirilerek bağımlı ve bağımsız değişkenler arasındaki ilişki daha doğru ve tutarlı biçimde değerlendirilir. Böylece hata varyansı azaltılır, grup farklılıkları ortaya çıkartılır ve tip II hatanın da düşürülmesi sağlanır [25]. Hata varyansının azaltılmasıyla istatistiksel anlamda analizin gücü arttırılmış olur. Literatür incelendiğinde ANCOVA kullanımıyla ilgili aşağıdaki koşullar sıralanmaktadır [28]:

i) Regresyon analizinde grup içi dağılımın homojen olması

ii) Bağımlı değişken ile ortak değişken arasındaki korelasyon katsayısının $R \geqslant 0,3$ olması

iii) $\quad x$ ve $y$ arasındaki ilişkinin doğrusal olmasıdır.

Kovaryans analizinde yer alan ortak değişkenin sürekli ve en az aralık ölçeğinde olması beklenmektedir. ANCOVA yapılırken önce grup içi regresyon eğilimi test edilir ardından düzeltilmiş grup ortalamaları test edilerek aralarında anlamlı farklılık olup olmadığı analiz edilir. Düzeltilmiş ortalamalar arasında anlamlı bir fark bulunması durumunda $F$ testi uygulanarak farkın hangi gruplar arasında olduğu araştırılır. Kovaryans analizi yapılabilmesi için bazı varsayımların yerine gelmesi gerekmektedir. Bu varsayımlar şöyle özetlenebilir [25], [29]:

-Analizde değerlendirilen gruplar birbirinden bağımsız olmalıdır.

-Grupların bağımlı değişkene ait dağılımı normal dağılıma uygun olmalı ve varyansların homojenliği sağlanmalıdır.

-Analizde yer alan ortak değişken değeri aralıklı veya oransal veri kategorisinde olmalıdır. edilmelidir.

-Birden fazla ortak değişken kullanımında çoklu doğrusallık (multicollinearity) olmamasına dikkat

- Ortak değişken ve bağımlı değişken arasında doğrusal bir ilişki olmalıdır.

\section{BİR GIDA İŞLETMESINDE TEDARIKK SÜRESININ ANOVA VE ANCOVA YÖNTEMLERİ İLE DEĞERLENDİRİLMESİ}

Tedarik zinciri yönetiminde, şirketler müşteri siparişlerini zincirleme iş anlaşmaları gereği istenen yer ve zamanda teslim etmek zorundadır. Bu çalışmada Türkiye'nin önemli gıda işletmelerinin birinde ortaya çıkan tedarik zinciri ağı yönetimindeki tedarik süresinin performansını etkileyen problemler değerlendirilmektedir. Buna göre işletmede yer alan lojistik ve tedarik zinciri departmanı tedarik süresini etkileyen faktörleri belirleyerek tedarik süresinin etkin biçimde değerlendirilmesini/iyileştirilmesini amaçlamaktadır. Çalışmada, üretimde kullanılacak hammaddelerin temin süresi tedarik süresi olarak değerlendirilmektedir. Bu süreyi tedarikçi sınıfı, malzeme çeşidi ve parti büyüklüğü gibi pek çok faktör etkilemektedir. Problemde yer alan farklı faktörler ve faktörlerin seviyesi işletmenin tedarik zinciri performansını önemli ölçüde etkilemekte, problemin çözümünü güçleştirmektedir. Karmaşık yapıdaki bu tedarik zinciri ağ performansı problemine uygun çözüm elde etmek için istatistiksel yöntemlerin uygulanmasına ihtiyaç vardır. Ele alınan problemde öncelikle değişkenler açıklanmış ardından kullanılan hipotezler ve uygulanan yöntem anlatılmıştır. 


\section{Problem Tanımı, Model ve Değişsenler}

$\mathrm{Bu}$ çalışmada yer alan etkin faktörler tedarik zinciri yönetimi departmanı ve satın alma biriminden alınan görüşler yardımıyla şu şekilde belirlenmiştir: Parti büyüklüğü, malzeme çeşidi, tedarikçiyle sözleşme imzalanması (yaptırım) ve işletmelerin puanlanması tedarik süresinin belirlenmesinde etkili faktörler olarak değerlendirilmiştir.

Ele alınan problemin çözümünde kullanılan faktör ve seviyeleri Tablo 1'de gösterilmiş̧tir. Faktör seviyeleri belirlenirken işletme ve problemin yapısıyla ilişkili uzman görüşlerinden ve literatürde kullanılan faktör seviyelerinden yararlanılmıștır. Buna göre biri kontrol değişken (ortak değişken-Covariate) olmak üzere üç bağımsız değişken ve bir bağımlı değişkenle deney tasarlanmış ve tam faktöriyel deney tasarımı kullanılmıştır.

Tablo 1. Tedarik süresinde etkili faktörler

\begin{tabular}{|c|c|c|c|c|}
\hline \multirow{2}{*}{ Faktörler } & \multicolumn{4}{|c|}{ Seviyeler } \\
\cline { 2 - 5 } & $\mathbf{1}$ & $\mathbf{2}$ & $\mathbf{3}$ & $\mathbf{4}$ \\
\hline Malzeme Çeşidi & Un & Yă̆ & Şeker & Yumurta \\
\hline Parti Büyüklügü & Büyük & Orta & Küçük & - \\
\hline Yaptırım & Var & Yok & - & - \\
\hline Tedarikçi puanı & \multicolumn{4}{|c|}{ Sürekli değişken } \\
\hline
\end{tabular}

Değişkenler hakkında detaylı bilgi aşağıda verilmiştir. Bağımsız değişkenler parti büyüklüğü, malzeme çeşidi, yaptırım ve tedarikçi sınıfıdır. Kontrol değişkeni tedarikçi puanıdır. Bağımlı değişken ise tedarik süresi olarak belirlenmiştir.

\section{Bă̆ımsız Değiskenler}

Malzeme Çeşidi: İşletme bir gıda firması olduğu için kullanılan ana malzemeler un, yağ, şeker ve yumurta şeklinde dört seviye olarak belirlenmiştir.

Parti Büyüklüğü: İşletme tedarikçilerden sipariş edilen malzemeleri büyük, orta ve küçük partiler halinde almaktadır. Parti büyüklüğü üç seviye olarak belirlenmiştir. Parti büyüklüğüne göre malzemelerin araca yüklenme süresi dolayısıyla tedarik süresi değişmektedir.

Yaptırım: İşletmenin sözleşme imzaladığı tedarikçilerle yaptıkları centilmenlik sözleşmesine göre ürün sipariş edildikten en geç 72 saat içinde firmaya ulaşması gerektiği şartı konulmuştur. Aksi durumda maddi yaptırım işleme konulacaktır. Buna göre işletmeyle imzalanan sözleşmeye göre yaptırımı olan ve olmayan şeklinde iki seviye belirlenmiştir.

\section{Kontrol Değisskeni (Covariate)}

Tedarikçi Puanı: Tedarikçilerin bazı kriterlere göre değerlendirilerek puanlanmasıdır. Bu kriterler ürünün tam ve/veya zamanında teslim edilmesi, acil sipariş durumunun gözetilip gözetilmemesi, kalite, ambalajlama, ürün sıcaklığı gibi kriterleri sağlayıp sağlamamalarına göre değerlendirilmektedir. Şirket tedarikçinin performans değerlendirmesinde üst üste aynı puan sınıflandırmasında olan tedarikçiyle çalışmayı durdurabilir. Tedarikçi puanı tedarikçinin sınıfını belirlemede kullanılan önemli bir parametredir. Tedarikçi puanı, tedarik süresini etkileyen sürekli bir değişkendir.

\section{Bağımlı Değișken}

Tedarik Süresi: Çalışmada hedeflenen amaç yukarda belirtilen faktörlere göre çıktı değişkeni olan tedarik süresinin belirlenmesidir. Bu sebeple tedarik süresi bağımlı değişkendir. Buna göre model hipotezleri aşağıdaki gibi oluşturulmuştur: 


\section{E. Hipotezler}

İstatistiksel analizler için gerekli olan hipotezler aşağıda sunulmuştur:

$F$ testi hipotezleri

$H_{0}$ : Amaç fonksiyonu değeri (tedarik süresi) parti büyüklüğü, malzeme çeşidi, yaptırım ve tedarikçi puanı parametrelerine bağlı olarak farklılık göstermez.

$H_{l}$ : Amaç fonksiyonu değeri parti büyüklüğü, malzeme çeşidi, tedarikçiyle imzalanan sözleşmenin varlığı ve tedarikçi puanı parametrelerine bağlı olarak farklılık gösterir.

$\underline{\text { Parti Büyüklüğü parametresi için } F \text { testi }}$

$H_{0}{ }^{l}: \mu_{1}=\mu_{2}=\mu_{3}=\ldots . .=\mu_{i}$

$H_{l}{ }^{l}:$ tüm $\mu_{\mathrm{i}}$ ler eşit değildir.

Malzeme Ceșidi parametresi için $F$ testi

$H_{0}^{2}: \mu_{1}=\mu_{2}=\mu_{3}=\ldots . .=\mu_{i}$

$H_{l}^{2}$ :tüm $\mu_{i}$ ler eşit değildir.

$\underline{\text { Yaptırım parametresi için } F \text { testi }}$

$H_{0}{ }^{3}: \mu_{1}=\mu_{2}=\mu_{3}=\ldots . .=\mu_{i}$

$H_{l}^{3}$ :tüm $\mu_{i}$ ler eşit değildir.

Tedarikçi Puanı parametresi için $F$ testi

$H_{0}^{4}: \mu_{1}=\mu_{2}=\mu_{3}=\ldots . .=\mu_{i}$

$H_{l}^{4}$ :tüm $\mu_{\mathrm{i}}$ ler eşit değildir.

F. Yöntem

Tam faktöriyel deney tasarımı, probleme yönelik birden çok faktör ve faktör seviyesi olduğunda problem sonucu üzerindeki etkiyi araştıran bir yöntemdir. Ancak faktör ve seviye sayısı arttığında bu yöntem tüm kombinasyonları denediği için maliyetli ve zaman alıcı olabilir. Bu durumda kesirli çok etkenli (fractional factorial) deney tasarımı daha avantajlı olmaktadır. Bu çalışmada probleme yol açan faktörlerin bağımlı değişken üzerindeki etkisi ve faktörlerin birbirleriyle etkileşimi tam faktöriyel deney tasarımı ile ölçülmektedir.

Deneyler üç tekrarlı olarak gerçekleşmiştir. Faktörlerin seviyeleri farklı olduğu için $(4 * 3 * 2) * 3=72$ adet deney yapılmıştır. Yapılan deney tasarımı ile önce ANOVA uygulanmış ardından kontrol parametresinin bağımlı değişken üzerinde etkisini görmek ve ilişkinin açıklanabilirliliğini artırmak için ANCOVA yapılmıştır. Buna göre, bağımlı değişkende etkisi olduğu düşünülen tedarikçi puanı kontrol faktörü (Covariate) olarak ele alındığında ANCOVA analizi ile, sadece bağımsız değişken olarak dikkate alındığında Varyans Analizi ile değerlendirilmiştir. ANCOVA analizinin daha açıklayıcı sonuçlar verdiği görülmüştür. Kovaryant değişkeninin hesaba katılması, ortalama hata karesini $(M S E)$ genellikle düşürmektedir. Bu nedenle ANCOVA yönteminin kullanılması, istatistiksel gücün arttırılması ve deneydeki yanlılığı azaltması bakımından ANOVA'ya göre avantaj sağlamaktadır [30].

ANOVA ve ANCOVA analizlerinin ardından ele alınan gruplar arasında anlamlı bir fark olup olmadığı post hoc testleri kullanılarak araştırılmıştır. Duncan ve Tukey testleri kullanılarak değişken seviyeleri arasındaki 


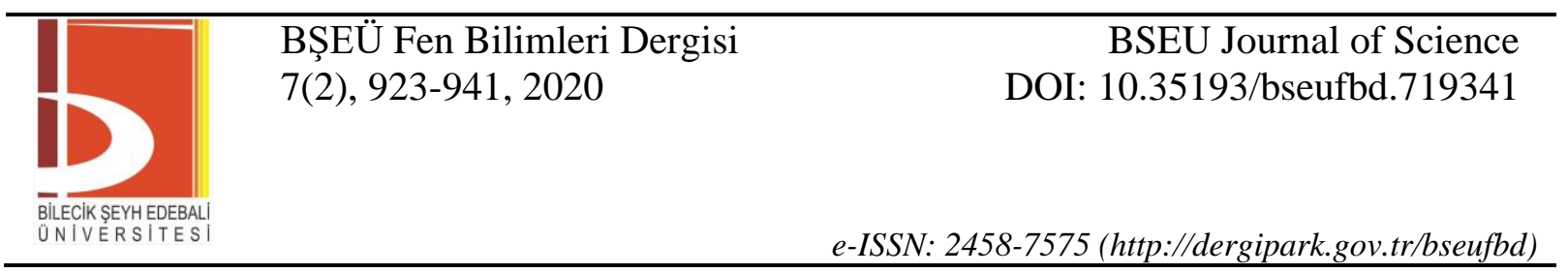

farklılıklar incelenmiştir. Faktörlerin performans ölçütü üzerindeki etkisi incelenirken ana etki (main effect) ve kovaryant değişkenle ana etki faktörlerinin ikili etkileşimleri (interaction effect) göz önüne alınmıştır.

ANCOVA analizi sırasında ana faktörler ile kovaryant değişkenin ikili etkileşimleri göz önüne alındığında faktörlerden birinin kovaryant değişkenle arasında yüksek korelasyon tespit edilmiştir. Buna göre korelasyon tespit edilen tedarikçi sınıfı faktörü modelden çıkartılarak analize devam edilmiştir. Pearson korelasyon değerini gösteren korelasyon tablosu Tablo 2'de gösterilmiştir.

Tablo 2. Korelasyon analizi

\begin{tabular}{|c|c|c|c|}
\hline \multicolumn{4}{|c|}{ Correlations } \\
\hline & & $\begin{array}{l}\text { Tedarikçi } \\
\text { Sınffi }\end{array}$ & $\underset{\text { ni }}{\text { tedarikci_pua }}$ \\
\hline \multirow[t]{3}{*}{ Tedarikçi Sınıfi } & Pearson Correlation & 1 &, 892 \\
\hline & Sig. (2-tailed) & &, 000 \\
\hline & $N$ & 72 & 72 \\
\hline \multirow[t]{3}{*}{ tedarikci_puani } & Pearson Correlation & $.892^{\prime \prime}$ & 1 \\
\hline & Sig. (2-tailed) &, 000 & \\
\hline & $\mathrm{N}$ & 72 & 72 \\
\hline
\end{tabular}

1) Verilerin Toplanması: Deneyler yapılırken deney tasarımı prensiplerine (tekrarlama, rassallık ve bloklama ilkeleri) uygun davranılmıştır.

2) Verilerin Gözden Geçirilmesi: Veriler değerlendirilirken eksik verilerin analizi için SPSS'te missing value analysis gerçekleştirilmiş ve eksik veri bulunmamıştır (Tablo 3 ).

Tablo 3. Eksik veri analizi

\begin{tabular}{|c|c|c|c|c|c|c|}
\hline \multicolumn{7}{|c|}{ Case Processing Summary } \\
\hline & \multicolumn{6}{|c|}{ Cases } \\
\hline & \multicolumn{2}{|c|}{ Valid } & \multicolumn{2}{|c|}{ Missing } & \multicolumn{2}{|c|}{ Total } \\
\hline & $\mathrm{N}$ & Percent & $\mathrm{N}$ & Percent & $\mathrm{N}$ & Percent \\
\hline Sözleşme & 72 & $100,0 \%$ & 0 & $0,0 \%$ & 72 & $100,0 \%$ \\
\hline $\begin{array}{l}\text { Parti } \\
\text { Büyüklüğü }\end{array}$ & 72 & $100,0 \%$ & 0 & $0,0 \%$ & 72 & $100,0 \%$ \\
\hline $\begin{array}{l}\text { tedarikci__ } \\
\text { puani }\end{array}$ & 72 & $100,0 \%$ & 0 & $0,0 \%$ & 72 & $100,0 \%$ \\
\hline $\begin{array}{l}\text { Malzeme } \\
\text { Türü }\end{array}$ & 72 & $100,0 \%$ & 0 & $0,0 \%$ & 72 & $100,0 \%$ \\
\hline
\end{tabular}

Tablo 4'te uç noktalar (outlier-dışa düşen) en yüksek ve en düşük değerlerine göre bulundukları gözlem sırasına göre verilmektedir. 


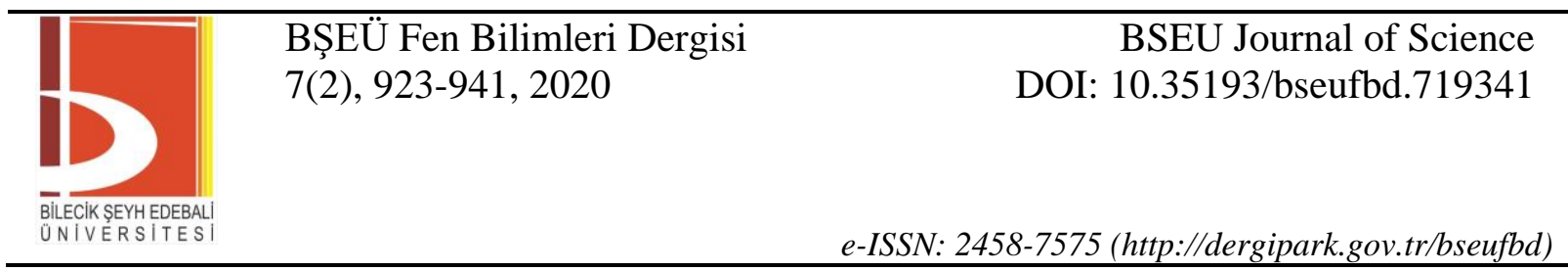

Tablo 4. Uç değerler tablosu

\begin{tabular}{|c|c|c|c|c|}
\hline \multicolumn{5}{|c|}{ Extreme Values $^{\mathrm{a}}$} \\
\hline \multicolumn{3}{|l|}{ tedarikci_puani } & $\begin{array}{c}\text { Case } \\
\text { Number }\end{array}$ & Value \\
\hline \multirow[t]{9}{*}{ tedarik_suresi } & Highest & 1 & 26 & 67 \\
\hline & & 2 & 50 & 66 \\
\hline & & 3 & 2 & 60 \\
\hline & & 4 & 51 & $48,00^{b}$ \\
\hline & Lowest & 1 & 4 & 30 \\
\hline & & 2 & 3 & 36 \\
\hline & & 3 & 28 & 38 \\
\hline & & 4 & 27 & 44 \\
\hline & Hirhest & 1 & $\Delta a$ & $11 \cap$ \\
\hline
\end{tabular}

3) Varsayımların Gözden Geçirilmesi: Kovaryans analizi için gereken varsayımlar şunlardır:

- Gruplar bağımsız olmalı, normal dağılıma uygun olmalı, varyansları eşit olmalıdır.

- Ayrıca, kontrol değiş̧keni (kovaryant) ve bağımlı değişken nicel verileri ölçmek için kullanılan aralıklı veya oransal veri şeklinde olmalıdır.

- Kovaryant değişkeni ile bağımlı değişken doğrusal bir ilişki göstermelidir.

\section{Normal dağılıma uygunluk varsayımı}

Verilerin normal dağılıma uygunluğu Kolmogorov Smirnov ve Shapiro-Wilk testi ile sınanmıştır. Her bir değişken ve seviyesi için hipotezler kurulmuş ve normallik testi yapılmıştır. Örneğin parti büyüklüğünde her üç seviye için tedarik sürelerinin normalliği aşağıda kurulan hipotezlerle sınanmaktadır.

\section{Küçük parti büyüklüğü için hipotezler;}

$H_{0}: \% 95$ güvenle veriler normal dağılımlıdır.

$H_{I}: \% 95$ güvenle veriler normal dağılımlı değildir.

Orta parti büyüklüğ̈̈ için hipotezler;

$H_{0}: \% 95$ güvenle veriler normal dağılımlıdır.

$H_{I}$ : \%95 güvenle veriler normal dağılımlı değildir.

Büyük parti büyüklüğü için hipotezler;

$H_{0}$ : \%95 güvenle veriler normal dağılımlıdır.

$H_{I}: \% 95$ güvenle veriler normal dağılımlı değildir. 


\begin{tabular}{|c|c|c|}
\hline & $\begin{array}{l}\text { BŞEÜ Fen Bilimleri Dergisi } \\
7(2), 923-941,2020\end{array}$ & $\begin{array}{l}\text { BSEU Journal of Science } \\
\text { DOI: } 10.35193 / \text { bseufbd. } 719341\end{array}$ \\
\hline & & 58-7575 (http://dergipark.gov.tr/bseufbd) \\
\hline
\end{tabular}

Tablo 5. Parti büyüklüğü için normallik testi

\begin{tabular}{|c|c|c|c|c|c|c|c|}
\hline \multicolumn{8}{|c|}{ Tests of Normality } \\
\hline \multirow{2}{*}{\multicolumn{2}{|c|}{ Parti Büyüklüğü }} & \multicolumn{3}{|c|}{ Kolmogorov-Smirnov $^{2}$} & \multicolumn{3}{|c|}{ Shapiro-Wilk } \\
\hline & & Statistic & df & Sig. & Statistic & df & Sig. \\
\hline \multirow{3}{*}{$\begin{array}{l}\text { tedarik_su } \\
\text { resi }\end{array}$} & Küçük &, 149 & 24 & ,181 &, 940 & 24 & , 164 \\
\hline & Orta & , 135 & 24 & $200^{\circ}$ & ,938 & 24 &, 146 \\
\hline & Büyük & , 122 & 24 & $200^{\circ}$ & 927 & 24 &, 082 \\
\hline
\end{tabular}

Tablo 5'te görüldüğü gibi "Shapiro-Wilk" testinin önem derecesi 0.05 ' ten büyük olduğundan tüm seviyeler için $H_{0}$ hipotezleri kabul edilir. Yani tüm gruplar için "\%95 güvenle veriler normal dağılır" denilmektedir.

Tablo 6. Sözleşme için normallik testi

\begin{tabular}{|c|c|c|c|c|c|c|c|}
\hline \multicolumn{8}{|c|}{ Tests of Normality } \\
\hline \multirow{2}{*}{\multicolumn{2}{|c|}{ Sözleșme }} & \multicolumn{3}{|c|}{ Kolmogorov-Smirnov $^{\mathrm{a}}$} & \multicolumn{3}{|c|}{ Shapiro-Wilk } \\
\hline & & Statistic & df & Sig. & Statistic & df & Sig. \\
\hline \multirow{2}{*}{$\begin{array}{l}\text { tedarik_su } \\
\text { resi }\end{array}$} & Var &, 142 & 36 &, 063 &, 950 & 36 &, 108 \\
\hline & Yok &, 148 & 36 &, 054 & ,933 & 36 &, 106 \\
\hline
\end{tabular}

Diğer değişkenler için de aynı şekilde hipotezler kurulup normallik testleri yapılmış ve tüm değişken seviyelerinin normal dağılıma uygunluk varsayımını sağladığı görülmüştür (Tablo 6-7).

Tablo 7. Malzeme türü için normallik testi

\begin{tabular}{|c|c|c|c|c|c|c|c|}
\hline \multicolumn{8}{|c|}{ Tests of Normality } \\
\hline \multirow{2}{*}{\multicolumn{2}{|c|}{ Malzeme Türü }} & \multicolumn{3}{|c|}{ Kolmogorov-Smirnov $^{3}$} & \multicolumn{3}{|c|}{ Shapiro-Wilk } \\
\hline & & Statistic & df & Sig. & Statistic & df & Sig. \\
\hline \multirow{4}{*}{$\begin{array}{l}\text { tedarik_su } \\
\text { resi }\end{array}$} & Tahıl & ,148 & 18 & $200^{2}$ & 961 & 18 &, 621 \\
\hline & Şeker & 205 & 18 &, 054 & ,847 & 18 & ,088 \\
\hline & Yağ &, 268 & 18 &, 061 & ,853 & 18 &, 070 \\
\hline & Yumurta &, 227 & 18 &, 515 & 903 & 18 &, 064 \\
\hline
\end{tabular}

Varyansların eșitliği varsayımı

Varyansların eşitliği varsayımı Levene testi ile sınanmıştır.

$H_{0:} \sigma_{1}^{2}=\sigma_{1}^{2}=\sigma_{2}^{2} \ldots=\sigma_{j}^{2}$

$H_{1:}$ tüm $\sigma_{j}^{2} e s s i t$ değildir. 


\begin{tabular}{|c|c|c|}
\hline & $\begin{array}{l}\text { BŞEÜ Fen Bilimleri Dergisi } \\
7(2), 923-941,2020\end{array}$ & $\begin{array}{l}\text { BSEU Journal of Science } \\
\text { DOI: } 10.35193 / \text { bseufbd.719341 }\end{array}$ \\
\hline & & 88-7575 (http://dergipark.gov.tr/bseufbd) \\
\hline
\end{tabular}

Tablo 8. Levene testi

\begin{tabular}{|c|c|c|c|}
\hline \multicolumn{4}{|c|}{$\begin{array}{c}\text { Levene's Test of Equality of Error Variances } \\
\text { Dependent Variable: tedarik suresi }\end{array}$} \\
\hline $\mathrm{F}$ & df1 & $\mathrm{df} 2$ & Sig. \\
\hline ,953 & 23 & 48 & 537 \\
\hline \multicolumn{4}{|c|}{$\begin{array}{l}\text { Tests the null bypothesis that the error variance of } \\
\text { the dependent variable is equal across groups. } \\
\text { a. Design: parti.buy + yaptirim + MALZEME + } \\
\text { tedarikci_puani }\end{array}$} \\
\hline
\end{tabular}

Tablo 8'de sunulan Levene testi sonucunda varyansların eşit olduğu varsayımı doğrulanmıştır $(p>0.05)$.

\section{ANALIZ}

Yapılan çalışmada öncelikle ANOVA analizi yapılarak hangi faktörlerin bağımlı değişken üzerinde anlamlı bir etkiye sahip olduğu araştırılmıştır. Ardından etkin olan faktörlerin hangi grupları arasında anlamlı bir fark olduğunun araştırılmasında Duncan ve Tukey testleri uygulanmıştır. Daha sonra kovaryant etki dikkate alınarak ANCOVA yapılmıştır.

G. ANOVA

Bağımlı ve bağımsız değişkenler arasındaki ilişkiyi test etmek için varyans analizi yapılmıştır.

Tablo 9. F Testi

Tests of Between-Subjects Effects

Dependent Variable: tedarik_suresi

\begin{tabular}{|l|r|r|r|r|r|}
\hline Source & $\begin{array}{c}\text { Type III Sum } \\
\text { of Squares }\end{array}$ & \multicolumn{1}{c|}{ df } & Mean Square & \multicolumn{1}{c|}{ F } & \multicolumn{1}{c|}{ Sig. } \\
\hline Model & $400598,931^{\text {a }}$ & 7 & 57228,419 & 387,401 &, 000 \\
parti_buy & 3057,194 & 2 & 1528,597 & 10,348 &, 000 \\
yaptirim & 2800,014 & 1 & 2800,014 & 18,954 &, 000 \\
MALZEME & 27374,375 & 3 & 9124,792 & 61,769 &, 000 \\
Error & 9602,069 & 65 & 147,724 & & \\
Total & 410201,000 & 72 & & & \\
\hline
\end{tabular}

a. $R$ Squared $=, 977$ (Adjusted R Squared $=, 974$ )

Tablo 9'a göre $F$ istatistiği değerleri incelendiğinde parti büyüklüğü, yaptırım ve malzeme çeşidi faktörlerinin tedarik süresi üzerinde $\alpha=0.05$ düzeyinde anlamlı bir etkiye sahip olduğu söylenmektedir. Buna göre $H_{o}$ hipotezleri red edilmektedir.

Etkin faktörlerin seviyeleri arasında farklılıkları görmek için Duncan ve Tukey çoklu aralık testleri uygulanmıştır. Post hoc testlerinde faktör seviyelerinin en az 3 olması gerekmektedir. Aşağıda faktör seviyesi üç ve dört olan faktörler (parti büyüklüğ̈̈ ve malzeme türü) için Duncan ve Tukey test analizleri verilmiştir. 
Tablo 10. Parti büyüklüğü için Tukey-Duncan testi

\begin{tabular}{|c|c|c|c|c|c|}
\hline & \multirow[b]{2}{*}{ Parti Büyüklüğü } & \multirow[b]{2}{*}{$N$} & \multicolumn{3}{|c|}{ Subset } \\
\hline & & & 1 & 2 & 3 \\
\hline \multirow[t]{4}{*}{ Tukey HSD ${ }^{a, b}$} & Küçük & 24 & 63,5417 & & \\
\hline & Orta & 24 & 71,2500 & 71,2500 & \\
\hline & Büyük & 24 & & 79,5000 & \\
\hline & Sig. & &, 079 &, 056 & \\
\hline \multirow[t]{4}{*}{ Duncan $^{a, b}$} & Küçük & 24 & 63,5417 & & \\
\hline & Orta & 24 & & 71,2500 & \\
\hline & Büyük & 24 & & & 79,5000 \\
\hline & Sig. & & 1,000 & 1,000 & 1,000 \\
\hline
\end{tabular}

Means for groups in homogeneous subsets are displayed

Based on observed means.

The error term is Mean Square(Error) $=147,724$.

Parti büyüklüğü küçük ve orta faktör seviyelerinin ortalamaları arasında anlamlı bir fark olmadığı ayrıca orta ve büyük seviyeleri arasında da anlamlı bir fark olmadığı görülmektedir (Tablo 10). Duncan testine göre ise parti büyüklüklerinin büyük, küçük ve orta seviyeleri için anlamlı fark olduğu görülmektedir. Ayrıca küçük partilerin tedarik süresinin daha kısa olduğu parti büyüklüğüne bağlı olarak tedarik süresinin uzadığı görülmektedir.

Tablo 11. Malzeme türü için Tukey-Duncan testi

\begin{tabular}{|c|c|c|c|c|c|}
\hline & \multirow[b]{2}{*}{ Malzeme Türü } & \multirow[b]{2}{*}{$N$} & \multicolumn{3}{|c|}{ Subset } \\
\hline & & & 1 & 2 & 3 \\
\hline \multirow[t]{5}{*}{ Tukey HSD ${ }^{a, b}$} & Yumurta & 18 & 51,1667 & & \\
\hline & Yağ & 18 & 56,3889 & & \\
\hline & Şeker & 18 & & 77,6667 & \\
\hline & Tahıl & 18 & & & 100,5000 \\
\hline & Sig. & &, 573 & 1,000 & 1,000 \\
\hline \multirow[t]{5}{*}{ Duncan $^{a, b}$} & Yumurta & 18 & 51,1667 & & \\
\hline & Yağ & 18 & 56,3889 & & \\
\hline & Şeker & 18 & & 77,6667 & \\
\hline & Tahıl & 18 & & & 100,5000 \\
\hline & Sig. & &, 202 & 1,000 & 1,000 \\
\hline
\end{tabular}

Malzeme türlerine göre yapılan Tukey ve Duncan testlerine göre yumurta ve yă̆ arasında anlamlı bir fark yoktur ancak şeker ve tahıl malzemeleri ve diğer seviyeler arasında anlamlı bir fark olduğu söylenebilir (Tablo 11).

\section{H. ANCOVA}

ANOVA analizinden sonra ANCOVA testi yapılarak çıkan sonuçlar karşılaştırılmıştır. Tedarikçi puanı kontrol değişkeni (kovaryant) olarak eklenmiştir. Buna göre kontrol değişkeninin bağımlı değişken üzerindeki açıklanma derecesi tespit edilmeye çalışılmıştır. 
Modele eklenen kontrol değişkeni ve bağımlı değişken doğrusal bir ilişki içinde olmalıdır. Bunu test etmek için iki değişken arasında korelasyon analizi yapılmıştır. Kontrol değişkeni ve bağımlı değişken arasındaki korelasyonun 0,30'dan yüksek olduğu durumlarda ANCOVA daha etkili olur. Tablo 12'de tedarik süresi ve tedarikçi puanı arasında anlamlı bir korelasyon tespit edildiği ve 0,3 'ten yüksek olduğu görülmektedir. Daha güçlü doğrusal ilişki daha güçlü ANCOVA sonuçlarının elde edilmesini sağlamaktadır.

Tablo 12. Tedarikçi puanı ve tedarik süresi arasında Pearson kolerasyon katsayı değeri

\begin{tabular}{|c|c|c|c|}
\hline \multicolumn{4}{|c|}{ Correlations } \\
\hline & & $\underset{\text { ni }}{\text { tedarikci_pua }}$ & tedarik_sures \\
\hline \multirow[t]{3}{*}{ tedarikci_puani } & Pearson Correlation & 1 &, $328^{\prime \prime}$ \\
\hline & Sig. (2-tailed) & &, 005 \\
\hline & $N$ & 72 & 72 \\
\hline \multirow[t]{3}{*}{ tedarik_suresi } & Pearson Correlation & $.328^{n \pi}$ & 1 \\
\hline & Sig. (2-tailed) &, 005 & \\
\hline & $\mathrm{N}$ & 72 & 72 \\
\hline
\end{tabular}

**. Correlation is significant at the 0.01 level (2-tailed).

Çalışmada tedarikçi puanı arttıkça tedarik süresinin düşeceği beklenildiğinden aralarındaki doğrusal ilişki sağlanmaktadır. Bu doğrusal ilişkinin sağlanmasında kovaryant değişkenine ( 1 / tedarikçi puanı) şeklinde matematiksel dönüşüm yapılarak ANCOVA varsayımına uyulmuştur.

Tablo 13. ANCOVA analiz tablosu

\section{Tests of Between-Subjects Effects}

Dependent Variable: tedarik_suresi

\begin{tabular}{|l|r|r|r|r|r|}
\hline Source & \multicolumn{1}{|c|}{$\begin{array}{c}\text { Type III Sum } \\
\text { of Squares }\end{array}$} & df & Mean Square & \multicolumn{1}{c|}{ F } & \multicolumn{1}{c|}{ Sig. } \\
\hline Model & $406189,890^{\mathrm{a}}$ & 8 & 50773,736 & 810,130 &, 000 \\
parti_buy & 3006,376 & 2 & 1503,188 & 23,984 &, 000 \\
yaptirim & 1715,626 & 1 & 1715,626 & 27,374 &, 000 \\
MALZEME & 30017,844 & 3 & 10005,948 & 159,652 &, 000 \\
tedarikci_puani & 5590,959 & 1 & 5590,959 & 89,208 &, 000 \\
Error & 4011,110 & 64 & 62,674 & & \\
Total & 410201,000 & 72 & & & \\
\hline
\end{tabular}

a. R Squared = ,990 (Adjusted R Squared $=, 989$ )

Tablo 13'e göre $F$ istatistiği değerleri incelendiğinde parti büyüklüğü, yaptırım ve malzeme çeşidi ve tedarikçi puanı faktörlerinin tedarik süresi üzerinde $\alpha=0.05$ düzeyinde anlamlı bir etkiye sahip olduğu söylenmektedir. Buna göre $H_{0}$ hipotezleri red edilmektedir.

\section{ANOVA ve ANCOVA Analizlerinin Karşılaştırılması}

Modele eklenen kovaryant değişkenin modelin açıklanabilirliliği üzerinde etkisi olup olmadığ incelenmiştir. ANCOVA analizi yapılmadan önce ANOVA analizinden elde edilen MSE değeri 147,724'tür. Tedarikçi puanının kovaryant faktör olarak eklenmesi ve bu faktörün bağımlı değişkeni doğrudan etkilediği, MSE değerinin 62,674'e düşmesiyle görülmektedir. Ayrıca ANOVA testinde düzeltilmiş $R^{2}$ (Adjusted $R^{2}$ ) değeri 0,974 iken ANCOVA analizinden sonra düzeltilmiş $R^{2}$ değeri artarak 0,989'a çıkmıştır. Bu değer eklenen kontrol parametresinin modelin açıklanabilirliliğine katkıda bulunduğunu göstermektedir.

$R^{2}$ deki değişimin anlamlılığını test etmek için aşağıdaki istatistik kullanılmıştır: 


$$
F=\frac{\left(R_{2}^{2}-R_{1}^{2}\right) /\left(k_{2}-k_{1}\right)}{\left(1-R_{2}^{2}\right) /\left(n-k_{2}\right)}=\frac{(0,99-0,977) /(4-3)}{(1-0,99) /(72-4)}=88,4
$$

$F_{\text {tablo }(1 ; 68)}=3$,98. Dolayısıyla $F_{\text {test }}>F_{\text {tablo }}$ olduğu için $H_{0}$ reddedilir. Burada kovaryant etkinin anlamlı olduğu görülmektedir. Kullanılan yöntemin tercih edilme nedeni açıklanırken aşağıdaki tespit vurgulanmıştır. Burada bu tespitin doğruluğu yeniden görülmektedir: "Kontrol değişkenin etkilerinin hesaba katılması, hata kareler ortalamasını genellikle düşürmektedir. Bu nedenle ANCOVA yönteminin kullanılması, istatistiksel gücün arttırılması ve deneydeki yanlılığı azaltması bakımından ANOVA'ya göre avantaj sağlar” [30].

Tablo 14'te ana etkilerin birbirlerinden bağımsız etkiye sahip olduğunu gösteren ana etkiler grafiği gösterilmektedir. Örneğin malzeme türü yumurta seçildiğinde parti büyüklüğü de küçükse tedarik süresinin en küçükleneceği görülmektedir. Ancak malzeme türü tahıl seçildiğinde ve parti büyük olduğunda tedarik süresinin uzayacağı görülmektedir. Ayrıca kontrol değişkeni olarak eklenen tedarikçi puanının parti büyüklüğü ve tedarik süresi faktörleriyle aralarında ilişki olmadığı görülmektedir. Kontrol değişkeni bağımsız değişkenlerden biriyle ilişkili olsaydı ANCOVA analizi doğru biçimde uygulanamaz, etkin sonuç sağlanmazdı.

Tablo 14. Değişkenler için ana etkiler modeli
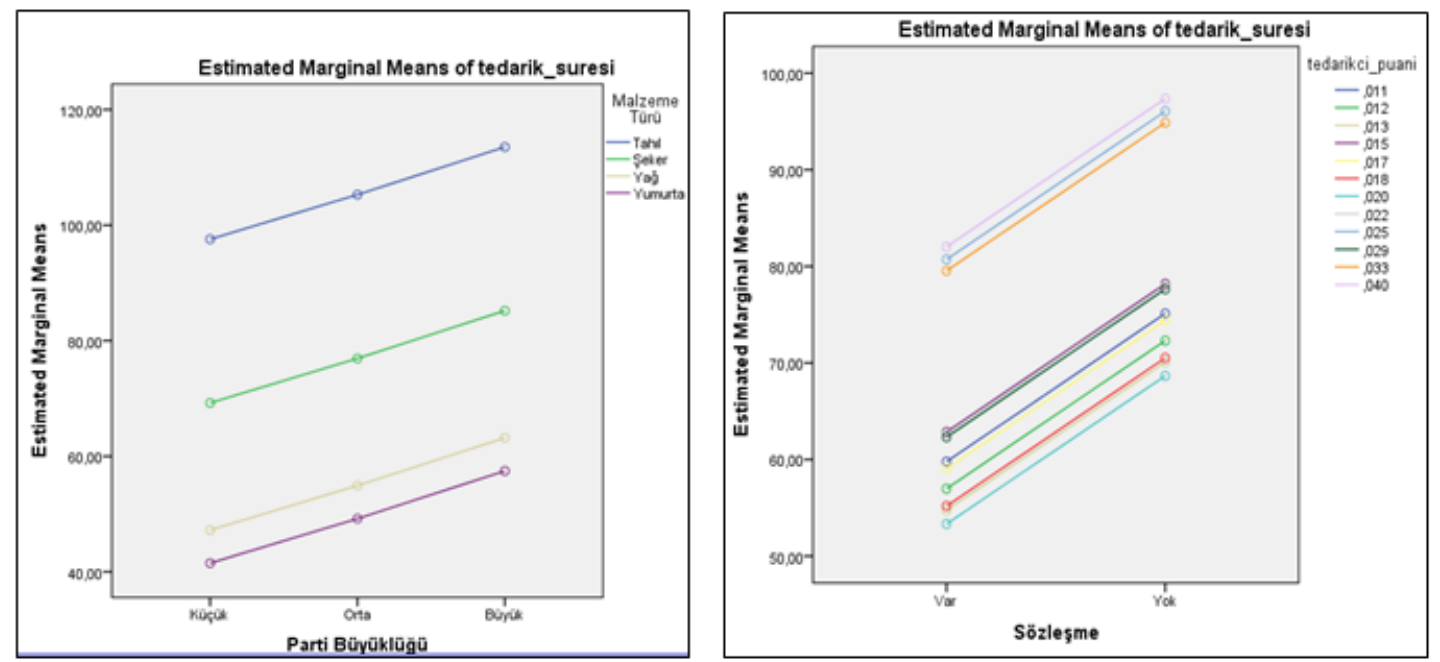

\section{SONUÇ VE ÖNERILER}

Küreselleşmenin hızla yaşandığı günümüz rekabet ortamında firmaların ayakta kalabilmesi doğru biçimde planlanmış üretim, tedarik ve lojistik faaliyetleri ile mümkündür. Tedarik zincirinin etkin yönetimi, hem araştırmacılar hem de piyasada söz sahibi karar vericiler için önemli bir araştırma alanıdır. İşletmeler için en önemli amaç müşteri memnuniyetinin sağlanmasıdır. Tedarik süresinin kısalması ile müşteri ihtiyaçları hızlı biçimde karşılanarak müşteri memnuniyeti sağlanmaktadır. Tedarik zinciri ağ yönetimi bu karşılıklı memnuniyeti en büyüklerken maliyeti de en küçüklemeye çalışmaktadır. Oluşturulacak çözüm yöntemleri bazen birbirine paralel amaçların bazen birbiriyle çelişen amaçların optimizasyonunu gerektirmektedir.

Bu çalışmada amaç Türkiye'de faaliyet gösteren önemli bir gıda işletmesinin tedarik süresine etki eden faktörlerin incelenerek işletmede taktiksel ve stratejik seviyede karar alınmasına yardımcı olmaktır. Buna göre, tedarikçi sınıfı, malzeme türü, sipariş büyüklüğü ve yaptırım faktörleri bağımsız değişken olarak belirlenmiş ve tedarikçi puanı kovaryant değişkeni olarak ANCOVA'ya katılmıştır. Yapılan ANOVA ve ANCOVA analizleri ile bağımlı değişken ve bağımsız değişkenler arasında anlamlı bir ilişki olduğu tespit edilmiştir. Anlamlı bir ilişki çıktığı için Post Hoc testleri ile farklı faktör seviyeleri arasındaki farklılık olup olmadığına bakılmıştır. ANCOVA analiziyle tedarikçi puanının model açıklanabilirliği üzerinde anlamlı bir etki yarattığı sonucuna 
ulaşılmaktadır. Böylece ANCOVA analizinde kurulan modelin istatistiksel anlamda daha güçlü ve etkin bir model olduğu gösterilmiştir.

Gelecek çalışmalar için örneklem büyüklüğü ve faktör sayısı artırılabilir. Ayrıca karar verme yöntemleri de kullanılarak daha kapsamlı bir analiz yapılabilir.

\section{KAYNAKLAR}

[1] Kehoe, D. \& Boughton, N. (2001). Internet-based supply chain management A classification of approaches to manufacturing planning and control. Int. J. Oper. Prod. Manag., vol. 21, no. 4, pp. 516-524, doi: 10.1108/01443570110381417.

[2] Selçuk, P. (2005). Tedarik Zincirinin Zamana Dayalı Performansının Ölçülmesi: Türk Otomotive Yan Sanayi Uygulamas1. Ankara Üniversitesi SBF Derg., vol. 60, no. 3, p. 1, doi: 10.1501/SBFder_0000001434.

[3] Yayla, A. Y. \& Hartomacıŏlu, S. (2011). Tedarikçi Değerlendirme Sürecinde Yapay Sinir Ağlarının Kullanımı ve Sektörel Bir Uygulama.

[4] Yangınlar, G.(2018).Tedarikçi Seçim Kriterlerinin Önemi. Avrasya Sos. ve Ekon. Araştırmaları Derg., vol. 5, no. 8, pp. 236-250, Accessed: Apr. 12, 2020. [Online]. Available: https://dergipark.org.tr/tr/pub/asead/issue/41059/496335.

[5] Aytekin, F. G. \& Özcan, B. (2020). Nitelikli Elektronik Sertifika (NES) Tedarik Sürecindeki Takımların ANOVA Metodu İle Performanslarının Değerlendirilmesi. İleri Teknol. Bilim. Derg., vol. 6, no. 1, pp. 41$\begin{array}{lllll}\text { 49,Accessed: } & \text { Apr. } & \text { 12, } & \text { [Online]. } & \text { Available: }\end{array}$ https://dergipark.org.tr/tr/pub/duzceitbd/issue/31760/286199.

[6] Yang, J. Q., Zhang, X. M., Fu, H. Y.\& Liu, C.(2017). Inventory competition in a dual-channel supply chain with delivery lead time consideration. Appl. Math. Model., vol. 42, pp. 675-692, doi: 10.1016/j.apm.2016.10.050.

[7] Fu, Y. C. \& Yeh, C. W. (2017). An integrated producer-buyer supply chain with delivery cost under stochastic transportation time. Appl. Math. Model., vol. 44, pp. 676-687,doi: 10.1016/j.apm.2017.02.038.

[8] Schniederjans, D. G., Curado, C. \& Khalajhedayati, M. (2020). Supply chain digitisation trends: An integration of knowledge management. Int. J. Prod. Econ., vol. 220, p. 107439, doi: 10.1016/j.ijpe.2019.07.012.

[9] Munir, M., Jajja, M. S. S., Chatha, K. A. \& Farooq S. (2020). Supply chain risk management and operational performance: The enabling role of supply chain integration. Int. J. Prod. Econ., vol. 227, p. 107667, Sep. 2020, doi: 10.1016/j.ijpe.2020.107667.

[10] Chen, X., Luo, J., Wang, X. \& Yang, D. (2020). Supply chain risk management considering put options and service level constraints. Comput. Ind. Eng., vol. 140, p. 106228, doi: 10.1016/j.cie.2019.106228.

[11] Helo P. \& Shamsuzzoha, A. H. M. (2020). Real-time supply chain-A blockchain architecture for project deliveries. Robot. Comput. Integr. Manuf., vol. 63, p. 101909, doi: 10.1016/j.rcim.2019.101909.

[12] Roy, V., Silvestre, B. S. \& Singh, S.(2020). Reactive and proactive pathways to sustainable apparel supply chains: Manufacturer's perspective on stakeholder salience and organizational learning toward responsible management. Int. J. Prod. Econ., vol. 227, p. 107672, doi: 10.1016/j.ijpe.2020.107672.

[13] Noori-Daryan, M., Taleizadeh, A. A. \& Jolai, F. (2019). Analyzing pricing, promised delivery lead time, supplier-selection, and ordering decisions of a multi-national supply chain under uncertain environment. Int. J. Prod. Econ., vol. 209, pp. 236-248, doi: 10.1016/j.ijpe.2017.12.019. 
[14] Öztürk, D. (2016). Tedarik Zinciri Yönetimi Süreçlerini Etkileyen Faktörler.

[15] Bandaly, D. , Satir, A. \& Shanker, L. (2016). Impact of lead time variability in supply chain risk management. Int. J. Prod. Econ., vol. 180, pp. 88-100, doi: 10.1016/j.ijpe.2016.07.014.

[16] Bowersox, D. J, La Londe, B. J. \& Smykay, E. W. (1969). Readings in physical distribution management; the logistics of marketing. New York: Collier Macmillan Ltd.

[17] Karasu, F. I. (2006).Tedarik Zinciri Yönetiminin Yapısı ve Issleyişi. Yüksek Lisans Tezi, Anadolu Üniversitesi Sosyal Bilimler Enstitüsü, Eskişehir.

[18] Özdemir, A. İ. (2004).Tedarik zinciri yönetiminin gelişimi, süreçleri ve yararları. Erciyes Üniversitesi Iktisadi ve İdari Bilim. Fakültesi Derg., no. 23.

[19] Lancioni, R. A., Smith, M. F. \& Schau, H. J.(2003).Strategic Internet application trends in supply chain management. Ind. Mark. Manag., vol. 32, no. 3, pp. 211-217, doi: 10.1016/S0019-8501(02)00264-X.

[20] Montgomery, D. C. (2005). Design and analysis of experiments. John Wiley \& Sons.

[21] Hamzaçebi ,C. \& Kutay, F.(2003). Taguchi Metodu: Bir Uygulama. Teknoloji, vol. 6, no. 3-4, pp. 7-17.

[22] Büyüköztürk, Ş. (1997). İki faktörlü varyans analizi. Ankara Univ. Egit. Bilim. Fak. Derg., vol. 30, no. 1, pp. 001-018, doi: 10.1501/egifak_0000000272.

[23] Nie, N. H.(1976). Spss Statistical Package for the Social Sciences, vol. 5, no. 1. Informa UK Limited.

[24] Howell, D. (2007). Statistical methods for psychology. Brantford Ont.: Resource Services Library.

[25] Selim, K. (2017). Kovaryans Analizi. J. Mood Disord., vol. 7, no. 1, pp. 73-78, doi: 10.5455/jmood.20161230045344.

[26] Ryan, J. M. \& Hess, R. K. (1991). Handbook of statistical procedures and their computer applications to education and the behavioral sciences. New York: McMillian Publishing Company.

[27] Howitt D. \& Cramer, D. L. P. (1997). An introduction to statistics in psychology. London: Prentice Hall.

[28] Frigon J.-Y. \& Laurencelle, L. (1993). Analysis of Covariance: A Proposed Algorithm. Educ. Psychol. Meas., vol. 53, no. 1, pp. 1-18, doi: 10.1177/0013164493053001001.

[29] Şenoğlu, B. \& Acıtaş, Ş.(2010). İstatistiksel Deney Tasarımı Sabit Etkili Modeller. Ankara: Nobel Yayın Dăğtım.

[30] Sahai, H. \& Ageel, M. I.(2000). The Analysis of Variance. Boston, MA: Birkhäuser Boston. 